\title{
СУЧАСНИЙ ПІДХІД ЩОДО ПРОВЕДЕННЯ КОНТРОЛЬОВАНОЇ СТИМУЛЯЦІї ЯСЧНИКІВ У ЦИКЛАХ ДОПОМГЖНИХ РЕПРОДУКТИВНИХ ТЕХНОЛОГІЙ У ЖІНОК ІЗ ВИСОКИМ РИЗИКОМ СИНДРОМУ ГІПЕРСТИМУЛЯЦІї ЯЄЧНИКІВ
}

СУЧАСНИЙ ПІДХІД ЩОДО ПРОВЕДЕННЯ КОНТРОЛЬОВАНОЇ СТИМУЛЯЦІї ЯЄЧНИКІВ У ЦИКЛАХ ДОПОМІЖНИХ РЕПРОДУКТИВНИХ ТЕХНОЛОГІЙ У ЖІНОК ІЗ ВИСОКИМ РИЗИКОМ СИНДРОМУ ГІПЕРСТИМУЛЯЦІї ЯЄЧНИКІВ. ВИкористання розроблених протоколів контрольованої стимуляції яєчників з антагоністом гонадотропін-рилізинг гормону 3 урахуванням рівня сироваткового прогестерону у програмі допоміжних репродуктивних технологій щодо жінок 3 високим ризиком розвитку синдрому гіперстимуляції яєчників дозволило зменшити кількість випадків середньо-тяжких фрорм синдрому гіперстимуляції яєчників (2,5 \% проти 17,5 \% у разі традиційної схеми 3 антагоністом гонадотропін-рилізинг-гормону; RR 0,14; 95 \% ДІ 0,04-0,46), підвищити частоту настання клінічної вагітності (35,0 \% проти 21,7 \%; RR 1,62; 95 \% ДI 1,06-2,46) і пологів (33,3 \% проти 16,7 \%; RR 2,00; 95 \% ДІ 1,25-3,21).

СОВРЕМЕННЫЙ ПОДХОД ОТНОСИТЕЛЬНО ПРОВЕДЕНИЯ КОНТРОЛИРОВАННОЙ СТИМУЛЯЦИИ ЯИЧНИКОВ В ЦИКЛАХ ВСПОМОГАТЕЛЬНЫХ РЕПРОДУКТИВНЫХ ТЕХНОЛОГИЙ У ЖЕНЩИН С ВЫСОКИМ РИСКОМ СИНДРОМА ГИПЕРСТИМУЛЯЦИИ ЯИЧНИКОВ. Использование разработанных протоколов контролируемой стимуляции яичников с антагонистом гонадотропин-рилизинг гормона с учетом уровня сывороточного прогестерона в программе вспомогательных репродуктивных технологий у женщин с высоким риском развития синдрома гиперстимуляции яичников позволило уменьшить число случаев средне-тяжелых форм синдрома гиперстимуляции яичников (2,5 \% против 17,5 \% при традиционной схеме с антагонистом гонадотропин-рилизинг-гормона; RR 0,14; $95 \%$ дИ 0,04-0,46), повысить частоту наступления клинической беременности (35,0 \% против 21,7 \%; RR 1,62; 95 \% ДИ 1,06-2,46) и родов (33,3 \% против 16,7 \%; RR 2,00; 95 \% ДИ 1,25-3,21).

MODERN APPROACH CONCERNING CONTROLLED OVARIAN STIMULATION IN CIRCLES OF ADDITIONAL REPRODUCTIVE TECHNOLOGIES IN WOMEN WITH HIGH RISK OF OVARIAN HYPER STIMULATION SYNDROME. Using the developed protocol controlled ovarian stimulation with an antagonist of gonadotropin-releasing hormone, taking into account the level of serum progesterone in the program of assisted reproductive technology in women at high risk of developing ovarian hyperstimulation syndrome reduced the number of medium-severe forms of ovarian hyperstimulation syndrome $(2.5 \%$ vs $17.5 \%$ with the traditional scheme with an antagonist of gonadotropin-releasing hormone; RR 0,14;95\% Cl 0,04-0,46), increase the frequency of clinical pregnancy (35.0 \% vs $21.7 \%$; RR 1.62; $95 \% \mathrm{Cl} 1.06-2.46$ ) and delivery (33.3 \% vs $16.7 \%$; RR 2.00; $95 \% \mathrm{Cl} 1.25-3.21$ ).

Ключові слова: допоміжні репродуктивні технології, контрольована стимуляція яєчників, антагоністи гонадотропінрилізинг-гормону, прогестерон, синдром гіперстимуляції яєчників.

Ключевые слова: вспомогательные репродуктивные технологии, контролируемая стимуляция яичников, антагонисты гонадотропин-рилизинг-гормона, прогестерон, синдром гиперстимуляции яичников.

Key words: assisted reproductive technology, controlled ovarian stimulation, antagonists gonadotropin-releasing hormone, progesterone, ovarian hyperstimulation syndrome.

ВСтУП. Методи допоміжних репродуктивних технологій (ДРТ), які передбачають проведення контрольованої стимуляції яєчників (КСЯ) з наступним забором ооцитів і заплідненням ïx in vitro, широко використовуються в клінічній практиці для лікування різних форм жіночого і чоловічого безпліддя [1-3]. Водночас існуючі види КСя, які передбачають використання стандартних доз індукторів, пов'язані зі значними фрінансовими витратами, супроводжуються побічними ефектами і ризиком розвитку синдрому гіперстимуляції яєчників (СГЯ) [1-3]. Успіхи фрармакології дозволили переглянути схеми КСЯ в програмах ДРТ. На сьогодні створено принципово новий клас аналогів гонадоліберину - антагоністи гонадотропін-рилізинг-гормону (ант-ГнРГ) [1-3]. Застосування ант-ГнРГ у протоколах КСЯ в циклах ДРТ відкриває нові можливості для індукції овуляції.

Метою роботи стала оцінка ефективності розробленого способу застосування ант-ГНРГ з урахуванням рівня сироваткового прогестерону при проведенні КСЯ щодо жінок з високим ризиком розвитку Сгя.
МАТЕРІАЛИ ТА МЕТОДИ. У дослідження УвіЙшли 240 безплідних жінок з високим ризиком виникнення СГЯ, які потребували проведення лікування безпліддя методами ДРТ, які були рандомізовані на дві групи: основна група (120 жінок) - пацієнтки, яким КСЯ проводили за розробленими протоколами з ант-ГнРГ (ганірелікс) з урахуванням рівня сироваткового прогестерону [3] та група порівняння (120 жінок) - за стандартним протоколом КСЯ з ант-ГнРГ (ганірелікс).

У роботі наведені параметри щодо визначення ефективності лікування, які використовують у проспективних дослідженнях, що рекомендується надавати з позицій доказової медицини [4].

Зниження абсолютного ризику (Absolute risk reduction, $A R R)$ - абсолютна арисретична різниця в частоті несприятливих наслідків між групами розробленого способу та традиційного. У разі різниці між групами сприятливих наслідків - підвищення абсолютної користі, через це часто цей показник називають «терапевтичною користю». 
Відносний ризик (relative risk, RR) або співвідношення ризиків (risk ratio) - відношення захворюваності серед осіб, які зазнали і не піддавалися певному впливу. Показує силу зв'язку між впливом і захворюванням. У нашому дослідженні відносний ризик показує силу зв'язку між впливом розробленого способу КСЯ і традиційного на ймовірність виникнення ускладнення.

Зниження відносного ризику (Relative Risk Reduction, $R R R)$ - відносне зменшення частоти несприятливих наслідків у групі розробленого способу у порівнянні з такою в групі традиційним способом. Зниження відносного ризику понад 50 \% відповідає клінічно значущому ефекту, від 25 до 50 \% - помірному ефекту, менше $25 \%$ - незначному есректу відносно до традиційних заходів.

Число хворих, яких необхідно лікувати (Number needed to treat, NNT) - спосіб оцінки відносної ефрективності двох методів лікування. Показує, яку кількість пацієнток необхідно піддати лікуванню досліджуваним методом щодо попередження несприятливого результату або сприятливого ефекту в одному випадку.

До цих показників розраховували $95 \%$ ДІ (Confidence interval, Cl), який показує, в яких межах можуть коливатися дійсні значення в популяції. Так, 95 \% ДІ означає, що істинне значення в 95 \% випадків знаходиться в межах розрахованого інтервалу. Якщо при порівнянні двох груп $95 \%$ ДІ не включав 1, результати вважалися статистично значущими на рівні 0,05. Показники, більше 1, вказували на підвищений ризик в одній групі в порівнянні з іншою; відношення, менше 1, вказує на знижений ризик, відношення, рівне 1, вказує на відсутність як підвищеного, так і зниженого ризику. Тільки коли $95 \%$ ДІ знаходиться поза 1, ризик буде підвищеним (чи зниженим) в $95 \%$ випадків.

РЕЗУЛЬТАТИ ДОСЛІДЖЕННЯ ТА ЇХ ОБГОВОРЕННЯ. За результатами клінічних досліджень відзначено, що в жінок основної групи СГЯ середнього ступеня розвився у 3 (2,5\%) жінок, позитивним моментом є відсутність жодного випадку у цій групі СГЯ тяжкого ступеня. Водночас у групі порівняння СГЯ середнього ступеня зареєстровано у 18 (15,0 \%) випадках, тяжкого ступеня - у 3 (2,5 \%). Отже, сумарна частота розвитку СГЯ середнього та тяжкого ступенів при проведенні ДРТ склала 2,5 \% (3 із 120), а в групі порівняння - 17,5% (21 із 120), тобто застосування
ант-ГнРГ при КСЯ з урахуванням рівня сироваткового прогестерону сприяло зниженню абсолютного ризику розвитку СГЯ середньо-тяжкого ступеня на 15,0 \% (95 \% ДІ 7,7-22,4 \%). За коефіцієнтом відносного ризику можна стверджувати, що ризик виникнення середньо-тяжких орорм СГЯ у жінок, які отримали розроблений спосіб застосування ант-ГнРГ при КСЯ з урахуванням сироваткового прогестерону, у сім разів нижчий, порівняно 3 традиційним способом. Запропонований спосіб дозволяє знизити відносний ризик середньо-тяжких фрорм СГЯ на 85,7 \%, що вказує на клінічно значиму ефективність (більше 50 \%). 3 клінічної точки зору, показник число хворих, яких необхідно лікувати, у нашому дослідженні свідчить, що при ДРТ для запобігання одному такому випадку Сгя запропонований спосіб необхідно використати у 6,7 (95 \% ДІ 4,5-13,1) пацієнток (табл. 1).

Слід вказати, що у 2 пацієнток основної групи і 8 групи порівняння перенесення ембріонів у порожнину матки було скасовано через високий ризик розвитку Сгя. У цих випадках проведено кріоконсервацію ембріонів із подальшим їх перенесенням у порожнину матки в природному циклі.

Результати проведеного дослідження свідчать про високий відсоток запліднення в основній групі, що може вказувати на добру якість ооцитів і ембріонів, отриманих при використанні розробленого способу стимуляції. Так, клінічну вагітність, індуковану ДРТ, зареєстровано у $35,0 \%$ жінок основної групи та у 21,7 \% групи порівняння, отже, «терапевтична користь» запропонованого способу застосування ант-ГнРГ при КСЯ з урахуванням рівня сироваткового прогестерону складала 13,3 \%. Подальшим дослідженням відзначено, що ймовірність настання вагітності, що розвивається, у разі використання розробленого способу у 1,62 $(1,06-2,46)$ раза вища, ніж за стандартним використанням протоколу КСЯ з ант-ГнРГ. Показник підвищення відносної користі, склавши 61,5\%, відповідав клінічно значимому ефекту розробленого способу (більше 50 \%). Число хворих, яким необхідно лікування, вказує на те, що на кожних 7,5 жінок, яким проводили КСЯ за розробленим способом, в однієї жінки буде індукована вагітність.

Мимовільним абортом вагітність завершилася у 2 $(1,7$ \%) жінок основної групи і у 6 (5,0%) групи порівняння,

Таблиця 1. Результати проведення ДРТ у досліджуваних групах

\begin{tabular}{|c|c|c|c|c|c|c|c|c|}
\hline \multirow[t]{2}{*}{ Показник } & \multicolumn{2}{|c|}{$\begin{array}{c}\text { Основна група } \\
(\mathrm{n}=120)\end{array}$} & \multicolumn{2}{|c|}{$\begin{array}{c}\text { Група } \\
\text { порівняння } \\
(\mathrm{n}=120)\end{array}$} & \multirow{2}{*}{$\begin{array}{c}\text { Зниження абсо- } \\
\text { лютного ризику } \\
\text { (95 \% ДІ), \% }\end{array}$} & \multirow[t]{2}{*}{$\begin{array}{c}\text { Відносний } \\
\text { ризик } \\
\text { (95 \% ДI) }\end{array}$} & \multirow{2}{*}{$\begin{array}{c}\text { Зниження } \\
\text { відносного } \\
\text { ризику } \\
\text { (95\% ДІ), \% } \\
\end{array}$} & \multirow{2}{*}{$\begin{array}{c}\text { Число хворих, } \\
\text { яким необхідно } \\
\text { лікування } \\
(95 \% \text { ДІ) } \\
\end{array}$} \\
\hline & $\mathrm{n}$ & $\%$ & $\mathrm{n}$ & $\%$ & & & & \\
\hline $\begin{array}{l}\text { СГЯ середнього та } \\
\text { тяжкого ступенів }\end{array}$ & 3 & 2,5 & 21 & 17,5 & $\begin{array}{c}15,0 \\
(7,7-22,4)\end{array}$ & $\begin{array}{c}0,14 \\
(0,04-0,46) \\
\end{array}$ & $\begin{array}{c}85,7 \\
(53,4-95,6) \\
\end{array}$ & $\begin{array}{c}6,7 \\
(4,5-13,1) \\
\end{array}$ \\
\hline $\begin{array}{l}\text { СГЯ середнього } \\
\text { ступеня } \\
\end{array}$ & 3 & 2,5 & 18 & 15,0 & $\begin{array}{c}12,5 \\
(5,5-19,5) \\
\end{array}$ & $\begin{array}{c}0,17 \\
(0,05-0,55) \\
\end{array}$ & $\begin{array}{c}83,3 \\
(44,9-95,0) \\
\end{array}$ & $\begin{array}{c}8,0 \\
(5,1-18,1) \\
\end{array}$ \\
\hline СГЯ тяжкого ступеня & - & - & 3 & 2,5 & $\begin{array}{c}2,5 \\
(-0,3-5,3)\end{array}$ & 0 & 100 & $\begin{array}{c}40 \\
(2,4-13,7)\end{array}$ \\
\hline Клінічна вагітність & 42 & 35,0 & 26 & 21,7 & $\begin{array}{c}-13,3 \\
(-24,6--2,1) \\
\end{array}$ & $\begin{array}{c}1,62 \\
(1,06-2,46) \\
\end{array}$ & $\begin{array}{c}-61,5 \\
(-145,5--6,3) \\
\end{array}$ & $\begin{array}{c}-7,5 \\
(-48,6--4,1) \\
\end{array}$ \\
\hline Мимовільні аборти & 2 & 1,7 & 6 & 5,0 & $\begin{array}{c}3,3 \\
(-1,2-7,9) \\
\end{array}$ & $\begin{array}{c}0,33 \\
(0,07-1,61) \\
\end{array}$ & $\begin{array}{c}66,7 \\
(-61,9-93,1) \\
\end{array}$ & $\begin{array}{c}30,0 \\
(12,7--84,1) \\
\end{array}$ \\
\hline Пологи & 40 & 33,3 & 20 & 16,7 & $\begin{array}{c}-16,7 \\
(-27,4--5,9) \\
\end{array}$ & $\begin{array}{c}2,00 \\
(1,25-3,21) \\
\end{array}$ & $\begin{array}{c}-100 \\
(-221,1--24,6)\end{array}$ & $\begin{array}{c}-6,0 \\
(-16,9--3,7) \\
\end{array}$ \\
\hline
\end{tabular}


отже, зниження абсолютного ризику склало лише 3,3 \% і ДІ цього показника містив 1, що вказувало про відсутність статистичної та відповідно клінічної значущості між групами. Така ж картина спостерігалася й за іншими коефіцієнтами даного показника. Показник числа хворих, яких необхідно лікувати, був вищий, ніж за попередніми показниками, що також вказувало на незначну перевагу розробленого способу порівняно з традиційним щодо зниження мимовільних абортів (табл. 1).

Інтегральним критерієм оцінки завершення вагітності після ДРТ є показник «take home baby». Слід вказати, що даний показник склав 33,3\%, а в групі порівняння - 16,7 \%, тобто підвищення абсолютної користі склало 16,7 \%. За коефріцієнтом відносного ризику можна стверджувати, що ймовірність пологів народження дитини у жінок після застосування розроблених протоколів 3 ант-ГнРГ з урахуванням рівня сироваткового прогестерону удвічі вища, ніж у разі традиційних протоколів. Використання розроблених протоколів дозволяє підвищити частоту сприятливого завершення лікування методами ДРТ на 100 \%, що вказує на клінічно значиму ефективність (більше $50 \%$ ). Коесріцієнт число хворих, яким необхідно лікування, означає, що з кожних 6 жінок, яким проводилася розроблена КСЯ, в однієї жінки відбулися пологи.

ВИСНОВОК. Використання розроблених протоколів КСЯ $з$ ант-ГнРГ з урахуванням рівня сироваткового прогестерону у програмі ДРТ щодо жінок з високим ризиком розвитку СГЯ дозволило зменшити кількість випадків середньо-тяжких фрорм СГЯ (2,5 \% проти $17,5 \%$ у разі традиційної схеми з антагоністом гонадотропін-рилізинггормону; відносний ризик 0,14; 95 \% ДІ 0,04-0,46), підвищити частоту настання клінічної вагітності (35,0\% проти 21,7 \%; відносний ризик 1,62; 95 \% ДІ 1,06-2,46) і пологів (33,3 \% проти 16,7 \%; відносний ризик 2,00; 95 \% ДІ 1,25-3,21).

ПЕРСПЕКТИВИ ПОДАЛЬШИХ ДОСЛІДЖЕНЬ. ПОдальше удосконалення та індивідуалізація протоколів КСЯ у програмах ДРТ дозволить запобігти СГЯ та іншим ускладненням ДРТ.

\section{СПИСОК ЛІТЕРАТУРИ}

1. Бесплодный брак. Современные подходы к диагностике и лечению : руководство / под ред. Г. Т. Сухих, Т. А. Назаренко. - 2-е изд., испр. и доп. - М. : ГЭОТАР-Медиа, 2010. - $784 \mathrm{c}$.

2. Допоміжні репродуктивні технології лікування безпліддя : навч. посіб. / за заг. ред. проф. Ф. В. Дахна, чл.-кор. НАМН України, проф. В. В. Камінського, проф. О. М. Юзька. - K., 2011. -338 c.
3. Чайка А. В. Спосіб застосування антагоністів гонадотропін-рилізинг-гормонів при контрольованій стимуляції яєчників для профілактики ускладнень та невдач при допоміжних репродуктивних технологіях : метод. рекомендації / А. В. Чайка, О. М. Носенко, Е. М. Айзятулова. - K., 2012. -22 C.

4. Котельников Г. П. Доказательная медицина. Научнодоказательная медицинская практика / Г. П. Котельников, А. С. Шпигель. - Самара : СамГМУ, 2000. - 116 с.

Отримано 15.02.16 